\title{
Empowering leadership and human resources through stimulating innovative behaviors in higher education*
}

\author{
Shofia Amin ${ }^{1}$, Amirul Mukminin ${ }^{2}$, Rike Setiawati ${ }^{3}$, \\ Fitriaty Fitriaty $^{4}$
}

\begin{abstract}
In the era of the Fourth Industrial Revolution, 4IR or Industry 4.0, since highly advanced technology largely replaced human works, many production activities of both goods and services were required to be innovative. The purposes of this study were to examine the role of energizing self-efficacy as a mediator of leadership empowering and innovative behavior to analyze the mediator's role of affective commitment between the two. A survey method was used by distributing online questionnaires to 617 lecturers in Indonesia. For researching the interrelation of empowering leadership, energizing self-efficacy, affective commitment, and innovative behavior via statistical examination of their interrelationship, we applied Stata 13 software to test the hypotheses. The results pinpointed the significant impact of empowering leadership on affective commitment, energizing self-efficacy, and innovative behavior. Energizing self-efficacy significantly influenced innovative behavior, but the impact vice versa is not significant. There was an indirect effect of empowering leadership on innovative behavior through energizing self-efficacy, but the affective commitment was not a mediator between
\end{abstract}

\footnotetext{
Received: 13-09-2021; accepted: 26-12-2021

1 Associate Professor, Universitas Jambi, Faculty of Economics and Business, Indonesia. Scientific affiliation: human resource management and organizational behavior. E-mail: shofiaamin@unja.ac.id.(Correspondingauthor)

2 Full professor, Universitas Jambi, Faculty of Education, Indonesia. Scientific affiliation: educational policy, international/higher/sociology of education. E-mail: amirul.mukminin@ unja.ac.id.

${ }^{3}$ Associate Professor, Universitas Jambi, Faculty of Economics and Business, Indonesia. Scientific affiliation: financial management, Islamic financial management. E-mail: rikesetiawati@unja. ac.id.

${ }^{4}$ Lecturer, Universitas Jambi, Faculty of Economics and Business, Indonesia. Scientific affiliation: management strategic, finance.E-mail: fitriaty@unja.ac.id.
} 
empowering leadership and innovative behavior. These findings indicated that lecturers could stimulate their innovative behaviors by increasing their selfefficacy through empowering leadership. Our research findings highlight the importance of enhancing innovative behavior, self-efficacy, and empowering leadership.

Key words: affective commitment, empowering leadership, energizing self-efficacy, innovative behavior

JEL classification: C83, D23, I23, J24, M12, M54

\section{Introduction}

The crucial role for stimulating lecturers' innovative behavior in the era of the Fourth Industrial Revolution, Industry 4.0, is taken by empowering leadership, energizing self-efficacy, and affective commitment. Nevertheless, the extent to which lecturers essentially perform more innovatively in response to higher job demands we argue here to be reliant upon the role of empowering leadership, energizing self-efficacy, and affective commitment obtained at work. The industrial revolution simply means a profound and radical change in the way humans produce goods and services that will affect the economic, social, and cultural system(Schwab, 2016). Starting with the industrial revolution 1.0, indicated by the discovery of a steam engine in the 18th century, we follow the way to the era of industrial revolution 4.0, called a digital revolution (Chudy et al., 2020). Of course, this change will affect the way of life, work, and how to relate to one another throughout the world. In order to make the organization able to survive in situations of uncertain business environment, dynamic and intense competition, innovation, and innovative behaviors are essential factors (Bani-Melhem et al., 2018; Hakimian et al., 2016; Akram et al., 2017).

The innovative behavior is very human-centric (Noopur and Dhar, 2019). Therefore, it is needed stimulation to arouse it. Previous researchers have proven that leaders play a major role in stimulating innovative behavior, including transformational leadership (Amankwaa et al., 2019), transformational-transactional leadership (Contreras et al., 2017), and relational leadership (Akram et al., 2017). However, previous studies that examined the relationship of leader behavior with innovative work behavior are still inconclusive and even, in some cases, are opposite (Contreras et al., 2017). The understanding of innovative behavior itself is still operationalized in variations; it often focuses on creativity in stimulating new ideas.

Along with the rapid changes in the 4.0 revolution era, not only organizations and employees are required to change, but the style of leadership, too. One of the concepts of a new leadership style that is different from the previous concept is empowering leadership (Rao Jada et al., 2019). 
Empowering leadership is a leadership activity in sharing power and autonomy in making decisions to the followers (Zhu et al., 2019). This empowerment will increase employee self-efficacy due to the leadership's trust in their competence and encourage them to participate in decision-making. Self-efficacy can encourage employees to dare to innovate. Empowering leadership will also strengthen affective commitment in the form of emotional bonds manifested by inspiring, loving, and belonging to the organization. A strong affective commitment will encourage employees to innovate because they love their work and striving to advance their instances.

Recent reviews summarized that individual and context variables interact to influence innovative behaviors in organizations (Pons et al., 2016). Unfortunately, previous studies on the antecedents of innovative behavior mostly used respondents from various technology-related manufacturing industries (Özarall, 2016). The innovative behavior of lecturers has not been widely studied to the best of the research team's knowledge. Meanwhile, in the era of revolution 4, universities must provide IT-based education. However, internet-based information technology is only a tool that will only help lecturers. The role of lecturers themselves cannot be replaced and they are required to innovate in giving lectures both offline and online. Lecturers as service providers in the higher education sector were also demanded to be innovative in the midst of intense competition between State, Private and Foreign Universities. Therefore, this research will focus on the innovative behavior of lecturers. The purpose of this study is to examine the role of energizing self-efficacy as a mediator between empowering leadership and innovative behavior and to examine the role of affective commitment as a mediator between empowering leadership and innovative behavior. By understanding the model that can stimulate the innovative behavior of lecturers, it is hoped that it can provide input for leaders to shape innovative behavior of lecturers in carrying out the teaching and learning process, conducting research, and quality community service. The body of the manuscript first begins by describing the theoretical background and hypotheses. Next, the literature review discusses the related studies. The method section provides details about the sample, data collection, and analysis. The manuscript next presents the empirical results to conclude with a discussion, limitations, and further research. Additionally, this study tested the following hypotheses:

H1: Empowering leadership is positive significantly related to innovative behavior

$\mathrm{H} 2$ : Empowering leadership is positive significantly related to energizing self-efficacy

H3: Empowering leadership is positive significantly related to affective commitment 
H4: Affective commitment is positive significantly related to innovative behavior

H5: Affective commitment acts as a mediator in the relationship between empowering leadership and innovative behavior

H6: Energizing self-efficacy is positive significantly related to innovative behavior

H7: Energizing self-efficacy acts as a mediator in the relationship between empowering leadership towards innovative behavior.

The remainder of this paper is organized as follows: Section 2 focuses on the literature review; Section 3 deals with the research methodology; Section 4 provides the empirical data and analysis; Section 5 provides the results and discussion, and Section 6 summarizes the conclusion.

\section{Literarure review}

\subsection{Empowering leadership and innovative behavior}

The term innovation is increasingly popular in the era of Industrial Revolution 4.0 that relies heavily on digital technology (Suendarti et al., 2020). The technology and business revolution facing enterprises has changed the nature of work to be more complex and requires intellectual employees to be able to adapt quickly, be proactive, and be innovative at work (Kurt, 2019). Employee empowerment is one of the strategies to deal with the situation of the technological and business revolution through providing flexibility for employees to make decisions, have authority and authority related to their field of work (Cheong et al., 2016). One of the ways to create employee empowerment is through empowering leadership.

Empowering leadership is a process to influence subordinates by dividing rules, supporting through motivation, and supporting in development to support their own experience from self-reliance, and working self-ability toward the whole organizational strategy (Subair and Oriogu, 2016) (Cheong et al., 2016) and Zhu et al. (2019) found that once individuals are empowered to take independent action, they are more likely to demonstrate innovative behavior. Refers to selfdetermination theory, it is said that the work environment influences the level of basic needs by providing necessary resources and motivation. Employees are expected to fulfill their needs for autonomy, competence, and relatedness in the context of empowering leadership because its key feature is the provision of autonomy and encouragement, which, in turn, might produce motivation (Kim, 2019). When employees satisfy their basic needs, they are likely to express positive 
attitudes and results because they are motivated in an autonomous context. These employees tend to invest effort in relatively challenging activities that might help to improve the work situation (Atitumpong and Badir, 2018). Thus, empowering leadership is likely to increase employee innovative behavior by fulfilling employees' basic needs.

Leaders who implement behaviors that empower their subordinates aimed to develop their leadership skills and encourage followers to do things on their initiative will tend to develop creative behavior (Lee et al., 2018). Employees who work with empowering leaders might be relatively open to trying new methods or applying new ideas. The studies of Amalia and Handoyo (2018) and Chow (2017) support that employees who are empowered and feel the leadership's support for new ideas and solutions to the problems faced will have the motivation to innovate in their work.

\subsection{Empowering leadership and self efficacy}

As initially at the first time by Bandura (2012), human behavior is the result of intrapersonal influences, the behavior of the individuals involved, and the strength of the environment around them. The interaction of these three variables raises selfconfidence in a person of his ability to successfully perform certain behaviors in certain situations and his expectations of the results of behavior which is called self-efficacy.

Individuals who have self-efficacy will have confidence in achieving success; they will manage their efforts and survive (persistence) when facing difficulties and stressful situations in achieving their goals. Thus, self-efficacy is a motivation that energizes employees to enthusiastically achieve goals (Salanova et al., 2011). The employee will have an opportunity to maximize their working ability using the best fit working methods. They will have more self-confidence in doing a task using their own ability

The study by Kim and Beehr (2017) found that there is a positive relationship between empowering leadership and self-efficacy. Empowering leadership will have an impact on increasing employee confidence to dare to try something new in the completion of their duties because employees are given the confidence to be creative in developing their potential. Self-efficacy is one aspect of self-knowledge which is the most influential in everyday human life because self-efficacy possesses the ability to influence the individual in determining what actions to take in order to achieve the set goal, and it includes estimates of the challenges (Rafiola et al., 2020). If someone has no confidence to deal with certain tasks or activities, then he will quickly switch to other tasks or activities avoiding a bigger effort needed to complete the task or activity. 


\subsection{Empowering leadership and affective commitment}

As one of three components of organizational commitment introduced by Meyer and Allen (1991), affective commitment is an employee's emotional attachment to, identification with, and involvement in the organization. Employees with strong affective commitment will stay in their jobs because they want to, not because they need to (Cesário and Chambel, 2017). Affective commitment will create if they are appreciated, valued, and liked by their colleagues. Empowering leadership that gives trust and appreciation to employees will lead to affective commitment. This is in line with the concept of social exchange theory that says when employees receive advantageous treatment, they feel obligated to respond in kind and remunerate the organization (Mahmoud et al., 2021).

\subsection{Self efficacy and affective commitment as mediator on the relationship between empowering leadership and innovative behavior.}

Innovation can be interpreted as all individual actions that are directed at the interests of the organization in which the introduction and application of new ideas are beneficial (Harel et al., 2020). Innovative work behavior appears as a form of innovation at the individual level (Echebiri, 2020). As cited by Hakimian et al. (2016) there are two types of innovative behavior, namely technical and administrative behavior. Technical innovation refers to the introduction and/ or application of new technologies, products, and services, while administrative innovations refer to the introduction and/or application of new procedures and policies. Both technical and administrative innovations are not solely influenced by internal factors. Innovative behavior at work often arises when an employee faces challenges in his work, has broad authority in carrying out his duties and responsibilities. Organizations must also be aware that a climate that supports individual activities can encourage innovation.

Although affective commitment has persistently been established to be concerned with workplace behaviors, the relationship is complicated and depends on the context and the involvement of other variables (ST-Hilaire and de la Robertie, 2018). That's why many researchers are interested to study the antecedents of affective commitment and their results show that organizational and personal characteristics are the antecedents. One of the organizational characteristics is the behaviors of the leader (Cheong et al., 2018). Through empowered leadership, it will lead to self-efficacy and affective commitment which is a stimulus for innovative behavior.

By having the opportunity to explore and implement solutions to problems in their work, employees have an affective commitment to their work. This is because they feel ownership of and responsibility for their work. If employees have the affective 
commitment they will be more involved in organizational activities (Khaskheli et al., 2020). High involvement in organizational activities will spur new ideas, create models that can be applied and useful ideas useful or solutions to problems. Affective commitment will encourage innovative behavior because there is an emotional bond to stay remain and to advance the organization. Also, individuals who have self-efficacy will have confidence in achieving success; they will manage their efforts and persistence when facing difficult and stressful situations in achieving their goals. Thus, self-efficacy is a motivation that energizes employees to enthusiastically achieve goals (Bojovic and Jovanovic, 2020). By having high self-efficacy, employees will dare to take risks for innovative behavior.

This is reinforced by the social exchange theory which explains that good treatment from the organization/leader will also be rewarded well by employees. Sharing power, authority, and responsibility to subordinates in making decisions will be rewarded by employees with an increase in emotional bonds in the form of affective commitment that stimulates innovative behavior at work (Gkorezis, 2016). Empowering leadership will also strengthen employee self-efficacy because leaders give confidence in their abilities. As is known, innovative behavior is only owned by people who have competence and self-confidence.

Based on the previous literature review, a theoretical framework was compiled that inhibits the influence of empowering leadership, energizing self-efficacy, and affective commitment to innovative behavior as illustrated below:

Figure 1: Research framework

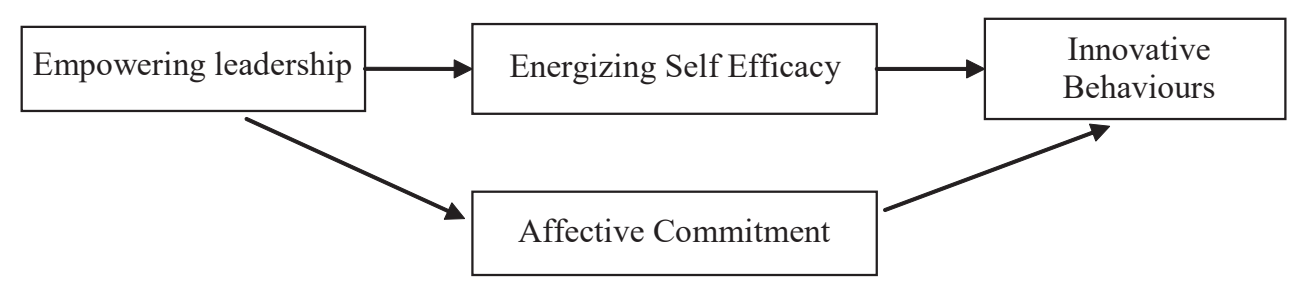

Source: Authors' research 


\section{Research methodology}

This study examined the role of empowering leadership, energizing selfefficacy, and affective commitment in stimulating lecturers' innovative behavior, testing the proposed hypotheses using a questionnaire prepared and elaborated by researchers based on a thorough literature review. The survey method used in this research helped develop a model to describe empowering leadership as a dependent variable, self-efficacy and affective commitment as a mediator, and innovative behavior as an independent variable. Then, we statistically examined the relationship between empowering leadership, energizing self-efficacy, affective commitment, and innovative behavior. The primary data were obtained directly by distributing questionnaires to selected respondents. Furthermore, to complement the primary data, the study also employed secondary data, collected from relevant agencies.

The research questionnaires of multiple-choice statements using $1-7$ Likert scales were prepared. It ranged from strongly disagree (value of 1) to strongly agree (value of 7). Empowering leadership is defined as the process of influencing employees through the distribution of power, motivation, and development support that aims to encourage subordinates to work freely, be motivated and can work independently in achieving organizational goals and strategies. Measured by adapting the 17 measures of empowering leadership scales proposed by Konczak et al. (2000). Energizing self-efficacy reflects self-confidence to succeed in carrying out a job in certain situations with the expectation of certain results. Measured by adapting a scale from Borgogni et al. (2010). Affective commitment is an employee's emotional bond to the organization as indicated by a strong belief, accepting the goals and values of the organization, and striving to realize the organization's goals as the first priority and maintain its membership. Measured by 8 questions adapted from Meyer and Allen (1991). Innovative behavior means the individual's ability to change the way of working in the form of adopting new procedures, practices, and work techniques in completing work. Measured using 10 questions adapted from Zhang (2010).

\section{Empirical data and results}

The population of this research is lecturers from various universities in Indonesia who have worked as lecturers for at least three years. The sample's choice is to strengthen the validity and reliability of affective commitment and innovative behavior. To be more accurate, the samples were selected by having a minimum of three years of service as civil servants. Because the population size is not known with certainty, we carried out the sampling by convenience sampling method and determined a target sample size of 500 people who would spread 
Shofia Amin et al. Empowering leadership and human resources through stimulating...

to various Indonesian universities using an online survey through the academic information system from Jambi University and the WhatsApp group of Indonesia Management Forum, Indonesian Research group, Publications of Management Lecturers and Alumni of postgraduate Airlangga University Surabaya for two months.

Then, for conducting the mediation test, it can be done without the precondition that the relation between the antecedent and the outcome should be significant. The mediation exists when the indirect effect is supported, regardless of the presence or absence of a direct effect (Aguinis et al., 2017). If the direct effect of the Independent Variable and the Dependent Variable is significant, there is a partial mediation. Conversely, if non-significant, there is a full mediation (Lachowicz et al., 2018).

Out of 735 questionnaires distributed online, we selected 617 as eligible for further processing. Following are the profiles of respondents in this study:

Table 1: Profil respondents

\begin{tabular}{|c|c|c|c|c|}
\hline \multicolumn{2}{|c|}{ Variable } & Observation & Number & Percentage \\
\hline \multirow{2}{*}{ Gender } & Female & \multirow[b]{2}{*}{617} & 295 & 52.19 \\
\hline & Male & & 322 & 47.81 \\
\hline \multirow{2}{*}{ Status } & Civil Servant & \multirow{2}{*}{617} & 379 & 61.43 \\
\hline & Non Civil Servant & & 238 & 38.57 \\
\hline \multirow{2}{*}{$\begin{array}{l}\text { Education } \\
\text { Qualification }\end{array}$} & S3 & \multirow{2}{*}{617} & 171 & 27.71 \\
\hline & S2 & & 446 & 72.29 \\
\hline \multirow{3}{*}{ Age } & $25-35$ & \multirow{3}{*}{617} & 177 & 28.69 \\
\hline & $36-46$ & & 178 & 28.85 \\
\hline & $\begin{array}{l}47-57 \\
>57\end{array}$ & & $\begin{array}{c}172 \\
90\end{array}$ & $\begin{array}{l}27.88 \\
14.58\end{array}$ \\
\hline
\end{tabular}

Source: Authors' research

Table 1 shows that the majority of respondents are men with the status of Civil Servants, Masters level education (S2) and aged 36-46 years.

\subsection{Validity and reliability}

Before conducting data analysis, the first step is to conduct a confirmatory factor analysis to ensure the accuracy of the data (Goodness of Fit) by reducing some indicators that do not meet the requirements. The following table describes the loading factor for each variable. 
Shofia Amin et al. • Empowering leadership and human resources through stimulating...

Tabel 2: Preliminary Results of CFA Construct Validity Analysis (Aspect-Indicators)

\begin{tabular}{|c|c|c|c|}
\hline Latent & Manifest & Loading Factor & P-Value \\
\hline \multirow{17}{*}{ EL } & EL1 & 0.60 & 0.00 \\
\hline & EL2 & 0.65 & 0.00 \\
\hline & EL3 & 0.60 & 0.00 \\
\hline & EL4 & 0.51 & 0.00 \\
\hline & EL5 & 0.36 & 0.00 \\
\hline & EL6 & 0.55 & 0.00 \\
\hline & EL7 & 0.59 & 0.00 \\
\hline & EL8 & 0.19 & 0.00 \\
\hline & EL9 & 0.48 & 0.00 \\
\hline & EL10 & 0.78 & 0.00 \\
\hline & EL11 & 0.80 & 0.00 \\
\hline & EL12 & 0.79 & 0.00 \\
\hline & EL13 & 0.75 & 0.00 \\
\hline & EL14 & 0.70 & 0.00 \\
\hline & EL15 & 0.71 & 0.00 \\
\hline & EL16 & 0.49 & 0.00 \\
\hline & EL17 & 0.73 & 0.00 \\
\hline \multirow{8}{*}{$\mathrm{AC}$} & $\mathrm{ACl}$ & 0.46 & 0.00 \\
\hline & $\mathrm{AC2}$ & 0.16 & 0.00 \\
\hline & $\mathrm{AC} 3$ & -0.13 & 0.00 \\
\hline & $\mathrm{AC} 4$ & -0.21 & 0.00 \\
\hline & $\mathrm{AC5}$ & 0.81 & 0.00 \\
\hline & AC6 & 0.82 & 0.00 \\
\hline & $\mathrm{AC7}$ & 0.21 & 0.00 \\
\hline & $\mathrm{AC} 8$ & 0.66 & 0.00 \\
\hline \multirow{6}{*}{ ESE } & ESE1 & 0.77 & 0.00 \\
\hline & ESE2 & 0.78 & 0.00 \\
\hline & ESE3 & 0.78 & 0.00 \\
\hline & ESE4 & 0.66 & 0.00 \\
\hline & ESE5 & 0.52 & 0.00 \\
\hline & ESE6 & 0.47 & 0.00 \\
\hline \multirow{8}{*}{ IB } & IB1 & 0.72 & 0.00 \\
\hline & IB2 & 0.69 & 0.00 \\
\hline & IB3 & 0.77 & 0.00 \\
\hline & IB4 & 0.58 & 0.00 \\
\hline & IB5 & 0.76 & 0.00 \\
\hline & IB6 & 0.70 & 0.00 \\
\hline & IB7 & 0.50 & 0.00 \\
\hline & IB8 & 0.47 & 0.00 \\
\hline
\end{tabular}

Source: Authors' research 
Shofia Amin et al. Empowering leadership and human resources through stimulating...

Refers to the results of the first CFA, not all standardized loading factors for the variables of empowering leadership, energizing self-efficacy, and innovative behavior had loading factors above 0.5. For empowering leadership variables, indicators EL5, EL8, EL9, EL16 have a loading factor below 0.5. For AC variables, only the AC5, AC6, and AC8 indicators have a loading factor above 0.5 . Meanwhile, the variables of energizing self-efficacy and innovative behavior are only the indicators ESE6 and IB 8 having a loading factor below 0.5. For the model to be fit and meet the requirements, all the indicators, not meeting the requirement, will be eliminated from the model.

Then the reliability test is measured using Construct Reliability (CR) and Average Variance Extracted (AVE) as presented in Table 3 below.

Table 3: Value of CR and AVE

\begin{tabular}{|c|l|c|c|}
\hline No & \multicolumn{1}{|c|}{ Variable } & CR & AVE \\
\hline 1 & Empowering Leadership (EL) & 0,91 & 0,46 \\
\hline 2 & Energizing Self Efficay (ESE) & 0.81 & 0.60 \\
\hline 3 & Affective Commitment (AC) & 0.83 & 0.51 \\
\hline 4 & Innovative Behavior (IB) & 0.86 & 0.46 \\
\hline
\end{tabular}

Source: Authors research

Based on the reliability construct calculation formula, the results obtained $\mathrm{CR}=0.81-0.91$ and $\mathrm{VE}=0.46-0.6$, which means that the variable has good reliability. As explained by Hair et al., (2010) that the construct has good reliability, if the value of Construct Reliability (CR) is $\geq 0.7$ and the value of variance extracted (VE) is $\geq 0.40$.

Furthermore, the value of goodness of fit is obtained as follows:

Table 4: Good of fit Criterion

\begin{tabular}{|c|l|c|c|c|}
\hline No & \multicolumn{1}{|c|}{ Criterion } & Value & Standard value & Information \\
\hline 1 & Chi Square $p$ & 0.00 & $>0.05$ & No Fit \\
\hline 2 & RMSEA & 0.057 & $<0.08$ & Fit \\
\hline 3 & SRMR & 0.049 & $<0.05$ & Fit \\
\hline 4 & TLI & 0,91 & $>0.90$ & Fit \\
\hline 5 & CFI & 0,92 & $>0.90$ & Fit \\
\hline
\end{tabular}

Source: Authors' research 
The results of the good of fit test show that the values of RMSEA, SRMR, TLI and CFI meet the required assessment standards. It can be concluded that the model built is in accordance with the sample data.

\subsection{Hypothesis testing}

The results of the hypothesis test are presented in Table 5 and Table 6.

Table 5: Direct effect

\begin{tabular}{|c|c|c|c|c|}
\hline Dependent & Independent & Coeficient & P-Value & Information \\
\hline $\mathrm{IB} \leq$ & EL & 0.17 & 0.00 & H1 accepted \\
\hline $\mathrm{ESE} \leq$ & EL & 0.44 & 0.00 & H2 accepted \\
\hline $\mathrm{AC} \leq$ & EL & 0.28 & 0.00 & H3 accepted \\
\hline $\mathrm{IB} \leq$ & AC & 0.04 & 0.33 & H4 rejected \\
\hline $\mathrm{IB} \leq$ & ESE & 0.42 & 0.00 & H5 accepted \\
\hline
\end{tabular}

Source: Authors' research

Based on the results illustrated in Table 5, it can be seen that empowering leadership variables have a positive significant effect on affective commitment, energizing self-efficacy, and innovative behavior. It means that the increased leadership that empowers subordinates directly will also increase affective commitment, selfefficacy, and innovative behavior.

Energizing self-efficacy has a positive effect on innovative behavior. On the other hand, affective commitment has a positive but not significant effect on innovative behavior. Increasing self-efficacy will directly increase innovative behavior, but increasing innovative behavior is not significantly influenced by increased affective commitment. All hypotheses are accepted, except for the fourth hypothesis that says that affective commitment is positive, significantly relating to rejected innovative behavior.

\subsection{Indirect effect}

Based on the results of data processing, it shows that the direct effect of empowering leadership on affective commitment is significantly positive, whereas, the direct effect of affective commitment on innovative behavior is insignificantly positive. It implies the effect of empowerment leadership increases affective commitment directly. However, although having affective commitment high, cannot increase innovative behavior both directly and indirectly. 
Shofia Amin et al. Empowering leadership and human resources through stimulating...

Table 6: Indirect Effect

\begin{tabular}{|c|c|c|c|}
\hline Variable & Coefficient & P-Value & Information \\
\hline $\mathrm{IB} \leq \mathrm{AC} \leq \mathrm{EL}$ & 0.01 & 0.33 & Not significant \\
\hline $\mathrm{IB} \leq \mathrm{ESE} \leq \mathrm{EL}$ & 0.18 & 0.00 & Significant \\
\hline
\end{tabular}

Source: Authors' research

Table 6 above shows that the value of the direct effect of empowering leadership on innovative behavior (0.17) is greater than the indirect effect through affective commitment (0.01). Hence, affective commitment does not act as a mediator between empowering leadership and innovative behavior. In other words, affective commitment as mediation between empowering leadership and innovative behavior was rejected.

The direct effect of empowering leadership on energizing self-efficacy is significantly positive. Also, the direct effect of emerging self-efficacy on innovative behavior is significantly positive. It implies, the effect of empowerment leadership increases energizing self-efficacy directly, and energizing self-efficacy increase innovative behavior directly.

The value of the direct effect of empowering leadership on innovative behavior $(0.17)$ is less than that of the indirect effect through energizing self-efficacy $(0.18)$. Hence, affective commitment acts as a fully mediating variable. To stimulate innovative behavior will be greater through increasing self-efficacy rather than through empowering leadership. In other words, energizing self-efficacy as mediation between empowering leadership and innovative behavior is accepted.

\section{Results and discussion}

There were five valuable findings of this study. First, the findings indicated that empowering leadership had a positive effect directly on innovative behavior. The current finding is in line with the results of previous studies and concluded that empowering leadership has a significantly positive and direct effect on innovative behavior (Gkorezis, 2016). It is because the lecturers have the freedom to manage their tasks. They also have the power to decide when and how to do their primary obligation.

Second, empowering leadership had a significant positive effect on energizing self-efficacy. It means that self-efficacy can be increased through the behavior of leaders who empower their subordinates. Empowering leadership means giving confidence to subordinates to complete their tasks autonomously, making decisions in completing tasks with their creativity. Thus empowering leadership also provides 
an opportunity for subordinates to develop their potential and increase competence. Someone will have self-efficacy if they have competence.

Third, empowering leadership had a significantly positive effect on affective commitment. Affective commitment is related to the emotion that encourages employees to remain loyal to the organization. Affective commitment is created because employees feel motivated to be allowed to develop their potential and gain trust. A pleasant behavior of the leader towards his/her employees will be rewarded by employees' positive attitudes in the form of affective commitment.

Fourth, energizing self-efficacy variable acted as a mediator on the relationship between empowering leadership and innovative behavior. Innovative behavior is influenced by courage to take risks and self-confidence. The courage to take risks will be owned by lecturers if they get good moral and material support from the leadership. Self-confidence will increase if they have the competence and are given the confidence and opportunity to actualize their competence. Empowering leadership has the characteristics of providing support and trust to its followers so that it can generate self-confidence and encourage innovative behavior.

Fifth, although empowering leadership had a significant direct effect on the affective commitment, the affective commitment did not have a significant direct effect on the innovative behavior. Meanwhile, energizing self-efficacy had a significant direct effect on innovative behavior. These findings indicated that affective commitment was unable to become a mediator between empowering leadership and innovative behavior. In particular, to enhance innovative behavior, it is preferred to increase self-efficacy through empowering leadership. The following are the managerial contributions of this study. Although empowering leadership improved self-efficacy and affective commitment, it stimulates innovative behavior more influenced by self-efficacy. This implied that leaders must stimulate the lecturers to enhance selfefficacy. Innovative behavior is only owned by people who have the competence and courage to take risks. People will have self-efficacy because they have competence. Then people will also dare to take risks because having self-efficacy will achieve success in their work. Through empowering leadership styles, it is hoped that lecturers' self-efficacy will continue to increase because they are given the trust and opportunity to always develop their own competencies.

\section{Conclusion}

Innovative behavior is more influenced by self-efficacy. To enhance innovative behavior, it is preferred to increase self-efficacy and empower leadership. This research presented a model for increasing innovative behavior through empowering leadership, energizing self-efficacy, and affective commitment. This study examined the role of empowering leadership, energizing self-efficacy, and affective 
commitment in stimulating lecturers' innovative behavior. The results confirmed the main hypothesis that empowering leadership had a directly positive effect on innovative behavior. We also found that empowering leadership had a significantly positive effect on energizing self-efficacy. For the other hypothesis, it indicated that empowering leadership had a significantly positive effect on affective commitment while energizing self-efficacy variable acted as a mediator on the relationship between empowering leadership and innovative behavior. Our study also indicated that affective commitment was unable to become a mediator between empowering leadership and innovative behavior.

Implications for higher education policies and programs can be drawn from the findings of this study. For example, rector, dean, head of the department, and head of the study program may assign tasks and responsibilities for lecturers accompanied by the authority in decision making so that it is possible for lecturers to behave innovatively in the learning process through using various teaching methods, conducting various research, and innovative community service.

This study contributes to the literature on empowering leadership, energizing selfefficacy, and affective commitment in stimulating lecturers' innovative behavior. Principally, our study focused on how empowering leadership, energizing selfefficacy and affective commitment could stimulate innovative behaviors for lecturers in higher education institutions.

The main limitation of this research is related to a simultaneous cross-data collection method while attitude measurement needs observation through timeseries data. Besides, the empirical data were gathered based on individual institutions while the discussion tends to be general; therefore further researchers are recommended to pursue research to see the findings based on time series data observation.

\section{Acknowledgments}

The authors would like to thank to the Faculty of Economics and Business, Universitas Jambi to have funded this research. We also thank to all participants of the study.

\section{References}

Akram, T., Lei, S., Haider, M. J. (2017) "The impact of relational leadership on employee innovative work behavior in IT industry of China", Arab Economic and Business Journal, Vol. 11, No. 2, pp. 153-161. https://www.researchgate. net/deref/http\%3A\%2F\%2Fdx.doi.org\%2F10.1016\%2Fj.aebj.2016.06.001. 
Amankwaa, A., Gyensare, M. A., Susomrith, P. (2019) “Transformational leadership with innovative behaviour: Examining multiple mediating paths with PLSSEM", Leadership and Organization Development Journal, Vol. 40, No. 4, pp. 402-420. https://doi.org/10.1108/LODJ-10-2018-0358.

Atitumpong, A., Badir, Y. F. (2018) "Leader-member exchange, learning orientation and innovative work behavior", Journal of Workplace Learning, Vol. 30, No. 1, pp. 32-47. https://doi.org/10.1108/JWL-01-2017-0005.

Bandura, A. (2012) "On the Functional Properties of Perceived Self-Efficacy Revisited", Journal of Management, Vol. 38, No. 1, pp. 9-44. https://doi. org/10.1177/0149206311410606.

Bani-Melhem, S., Zeffane, R., Albaity, M. (2018) "Determinants of employees' innovative behavior", International Journal of Contemporary Hospitality Management, Vol. 30, No. 3, pp. 1601-1620. doi:10.1108/ijchm-02-2017-0079.

Bojovic, I., Jovanovic, S. S. (2020) "Transformational Leadership and Psychological Needs of Employees”, Technium:Social Science Journal, Vol. 7. www.techniumscience.com.

Cesário, F., Chambel, M. J. (2017) "Linking Organizational Commitment and Work Engagement to Employee Performance", Knowledge and Process Management, Vol. 24, No. 2, pp. 152-158. https://doi.org/10.1002/kpm.1542.

Cheong, M. et al. (2016) "Two faces of empowering leadership: Enabling and burdening", Leadership Quarterly, Vol. 27, No. 4, pp. 602-616. https://doi. org/10.1016/j.leaqua.2016.01.006.

Cheong, M. et al. (2018) "A review of the e ff ectiveness of empowering leadership", The Leadership Quarterly, Vol. 30, No. 1, pp. 34-58. https://doi. org/10.1016/j.leaqua.2018.08.005.

Chow, I. H. S. (2017) "The mechanism underlying the empowering leadershipcreativity relationship", Leadership \& Organization Development Journal, Vol. 39, No. 2. https://doi.org/10.1108/LODJ-03-2016-0060.

Chudy, S. et al. (2020) "Contemplative insight as an opinion conflict and a search for meaning in the context of innovative elements of the revolution industry 4.0." In Education and Information Technologies. https://doi.org/10.1007/ s10639-020-10279-0.

Contreras, F. et al. (2017) 'Leadership and Employees' Innovative Work Behavior: Test of a Mediation and Moderation Model", Asian Social Science, Vol. 13, No. 9. https://doi.org/10.5539/ass.v13n9p9.

Gkorezis, P. (2016) "Principal empowering leadership and teacher innovative behavior: a moderated mediation model", International Journal of Educational Management, Vol. 30, No. 6. http://dx.doi.org/10.1108/IJEM-08-2015-0113\%0ADownloaded.

Hakimian, F. et al. (2016) "Importance of commitment in encouraging employees' innovative behaviour", Asia-Pacific Journal of Business Administration Vol. 8, 
No. 1. https://www.emerald.com/insight/content/doi/10.1108/APJBA-06-20150054/full/html.

Harel, R., Schwartz, D., Kaufmann, D. (2020) "Organizational culture processes for promoting innovation in small businesses", EuroMed Journal of Business, Vol. 16, No. 2. https://doi.org/10.1108/EMJB-03-2020-0027.

Kim, M., Beehr, T. A. (2017) "Self-Efficacy and Psychological Ownership Mediate the Effects of Empowering Leadership on Both Good and Bad Employee Behaviors\# Journal of Leadership and Organizational Studies, Vol. 24, No. 4, pp. 466-478. https://doi.org/10.1177/1548051817702078.

Kurt, R. (2019) "Industry 4.0 in Terms of Industrial Relations and Its Impacts on Labour Life", Procedia Computer Science, Vol. 158, pp. 590-601. https://doi. org/10.1016/j.procs.2019.09.093.

Lachowicz, M. J., Preacher, K. J., Kelley, K. (2018) “A novel measure of effect size for mediation analysis", Psychological Methods, Vol. 23, No. 2, pp. 244-261. https://doi.org/10.1037/met0000165.

Lee, A., Willis, S., Tian, A. W. (2018) "Empowering Leadership: A Meta-Analytic Examination of Incremental Contribution, Mediation, and Moderation", Journal of Organizational Behavior, Vol. 39, No. 3, pp. 306-325. https://doi. org/10.1002/job.2220.

Mahmoud, S. et al. (2021) "The Mediating Role of Psychological Contract Fulfillment in the Relationship Between Organizational Support and Employee Performance" Psychology and Behavioral Sciences, Vol. 10, No. 1, pp. 25-38. https://doi.org/10.11648/j.pbs.20211001.14.

Noopur, N., Dhar, R. L. (2019) "Knowledge-based HRM practices as an antecedent to service innovative behavior: A multilevel study", Benchmarking, Vol. 27, No. 1, pp. 41-58. https://doi.org/10.1108/BIJ-10-2018-0329.

Özarall, M. (2015) "Linking Empowering Leader to Creativity: The Moderating Role of ScienceDirect Linking empowering leader to creativity : the moderating role of psychological ( felt ) empowerment", Procedia - Social and Behavioral Sciences, Vol.181, pp. 366-376. https://doi.org/10.1016/j.sbspro.2015.04.899.

Pons, F. J., Ramos, J., Ramos, A. (2016) "Antecedent variables of innovation behaviors in organizations: Differences between men and women", Revue Europeenne de Psychologie Appliquee, Vol. 66, No. 3, pp. 117-126. https://doi. org/10.1016/j.erap.2016.04.004.

Rafiola, R. H. et al. (2020) "The effect of learning motivation, self-efficacy, and blended learning on students' achievement in the industrial revolution 4.0.", International Journal of Emerging Technologies in Learning, Vol. 15, No. 8, pp. 71-82. https://doi.org/10.3991/ijet.v15i08.12525.

Rao Jada, U., Mukhopadhyay, S., Titiyal, R. (2019) "Empowering leadership and innovative work behavior: a moderated mediation examination", Journal of 
Knowledge Management, Vol. 23, No. 5, pp. 915-930. https://doi.org/10.1108/ JKM-08-2018-0533.

Salanova, M. et al. (2011) "Linking transformational leadership to nurses' extrarole performance: The mediating role of self-efficacy and work engagement", Journal of Advanced Nursing, Vol. 67, No. 10, pp. 2256-2266. https://doi. org/10.1111/j.1365-2648.2011.05652.x.

Schwab, K. (2016) The Fourth Industrial Revolution what it means and how to respond World Economic Forum. https://www.weforum.org/agenda/2016/01/ the-fourth-industrial-revolution-what-it-means-and-how-to-respond/.

ST-Hilaire, W. A., de la Robertie, C. (2018) "Correlates of affective commitment in organizational performance: Multi-level perspectives", Australian Journal of Career Development, Vol. 27, No. 1, pp. 3-8. https://doi.org/10.1177/ 1038416217744215.

Subair, R. E., Oriogu, C. D. (2016) "Still an issue The use of electronic books in university libraries in Nigeria", American Journal of Social Sciences and Humanities, Vol. 1, No. 2, pp. 67-72. https://www.academia.edu/30328134/ STILL_AN_ISSUE_THE_USE_OF_ELECTRONIC_BOOKS_IN UNIVERSITȲ_LIBRARIES_IN_NIGERIA.

Suendarti, M., Widodo, W., Hasbullah, H. (2020) "Demonstrating The Effect of Grit and Creativity on Innovative Behavior of Teacher' s Natural Science: Mediating by Self -Efficacy", Journal of Xian University of Architecture and Technology, Vol. 12, No. 6, pp. 470-478.

Zhu, J., Yao, J., Zhang, L. (2019) "Linking empowering leadership to innovative behavior in professional learning communities: the role of psychological empowerment and team psychological safety", Asia Pacific Education Review, Vol. 20, No. 4, pp. 657-671. https://doi.org/10.1007/s12564-019-09584-2. 


\title{
Osnaživanje vodstva i ljudskih potencijala kroz poticanje inovativnog ponašanja u visokom obrazovanju
}

\author{
Shofia Amin ${ }^{1}$, Amirul Mukminin ${ }^{2}$, Rike Setiawati ${ }^{3}$, Fitriaty Fitriaty ${ }^{4}$
}

\begin{abstract}
Sažetak
U eri četvrte industrijske revolucije, $4 I R$ ili industrije 4.0, budući da je visokonapredna tehnologija uvelike zamijenila ljudske radove, mnoge proizvodne aktivnosti i roba i usluga morale su biti inovativne. Svrha ove studije bila je ispitati ulogu poticanja samoefikasnosti kao posrednika osnaživanja vodstva i inovativnog ponašanja kako bi se analizirala posrednička uloga afektivne predanosti između njih dvoje. Korištena je anketna metoda distribucijom online upitnika za 617 predavača u Indoneziji. Za istraživanje međuodnosa osnaživanja vodstva, jačanja samoučinkovitosti, afektivne predanosti i inovativnog ponašanja putem statističkog ispitivanja njihove međusobne povezanosti, primijenili smo softver Stata 13 za testiranje hipoteza. Rezultati su ukazali na značajan utjecaj osnaživanja vodstva na afektivnu predanost, poticanje samoučinkovitosti i inovativno ponašanje. Energiziranje samoučinkovitosti značajno je utjecalo na inovativno ponašanje, ali utjecaj obrnuto nije značajan. Postojao je neizravan učinak osnaživanja vodstva na inovativno ponašanje kroz poticanje samoučinkovitosti, ali afektivna predanost nije bila posrednik između osnaživanja vodstva i inovativnog ponašanja. Ovi nalazi su pokazali da bi predavači mogli stimulirati svoje inovativno ponašanje povećanjem svoje samoučinkovitosti kroz osnaživanje vodstva. Naši rezultati istraživanja ističu važnost poboljšanja inovativnog ponašanja, samoučinkovitosti $i$ osnaživanja vodstva.
\end{abstract}

Ključne riječi: afektivna predanost, predavač, osnaživanje vodstva, poticanje samoučinkovitosti, inovativno ponašanje

JEL klasifikacija: C83, D23, I23, J24, M12, M54

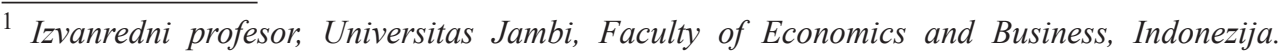
Znanstveni interes: upravljanje ljudskim resursima $i$ organizacijsko ponašanje. E-mail: shofiaamin@unja.ac.id. (osobaza kontakt)

2 Redoviti profesor, Universitas Jambi, Faculty of Education, Indonezija. Znanstveni interes: obrazovna politika, sociologija međunarodnog i visokog obrazovanja. E-mail: amirul. mukminin@unja.ac.id.

${ }^{3}$ Izvanredni profesor, Universitas Jambi, Faculty of Economics and Business, Indonezija. Znanstveni interes: financijski menadžment, islamski financijski menadžment. E-mail: rikesetiawati@unja.ac.id.

4 Predavač, Universitas Jambi, Faculty of Economics and Business, Indonezija. Znanstveni interes: strateški menadžment, financije.E-mail: fitriaty@unja.ac.id. 